\title{
CHRONIC EFFECTS OF ENVIRONMENTAL BIOMASS SMOKE ON LUNG HISTOPATHOLOGY IN TURKISH NON-SMOKING WOMEN: A CASE SERIES
}

\author{
Hulya GUNBATAR ${ }^{1}$, Bunyamin SERTOGULLARINDAN², Bulent OZBAY², Serhat AVCU ${ }^{3}$, \\ Gülay BULUT ${ }^{4}$, and Mustafa KOSEM ${ }^{5}$
}

Department of Pulmonary Medicine, Patnos State Hospital, Agri ${ }^{1}$, Department of Pulmonary and Critical Care Medicine, Medical Faculty of Yuzuncu Yil University², Department of Radiological Medicine, Medical Faculty of Yuzuncu Yil University ${ }^{3}$, Department of Pathology, Yuksek Ihtisas Hospital ${ }^{4}$, Department of Pathology, Medical Faculty of Yuzuncu Yil University, Van, Turkey

Received in February 2012

CrossChecked in June 2012

Accepted in June 2012

\begin{abstract}
Biomass is widely used for fuel in developing countries. Particles and gases of biomass burning may cause changes in the lung. In this prospective study we investigated histopathological changes in the lungs of 42 non-smoking women [mean age $(59 \pm 10)$ years] caused by biomass smoke. We valuated exposure to biomass smoke, case histories, and the findings of physical examination, radiology, bronchoscopy, and

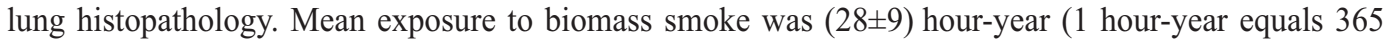
hours of exposure per year with average exposure of 1 hour a day). The radiological findings were mass (42\%), reticulonodular opacities (31\%), mediastinal lymphadenopathy $(26 \%)$, pleuro-parenchymal fibrotic banding $(19 \%)$, widening of the pulmonary artery $(14 \%)$, ground glass $(11 \%)$, mosaic perfusion $(9 \%)$, consolidation $(9 \%)$, segmental or subsegmental atelectasis $(7 \%)$, and bronchiectasis $(7 \%)$. The patients were diagnosed with lung cancer (35\%), interstitial lung disease (31\%), sarcoidosis $(9 \%)$, tuberculosis $(9 \%)$, chronic obstructive pulmonary disease $(4 \%)$, chronic bronchitis $(9 \%)$, and metastasis (4\%). Bronchoscopy showed pilies, oedema, erythema, bronchus narrowing, endobronchial tumour, mucosal irregularity, increased vascularisation, blue-black anthracotic plaques, mucosal oedema, and purulent secretion. Transbronchial biopsies revealed neutrophil and lymphocyte leucocytes in the perivascular, peribronchiolar, and interalveolar septa, slightly enlarged connective tissue, thickening of the basal membrane, thickening of interalveolar septa, intimal and medial thickening of the vascular wall and vascular lumen narrowing, anthracosis between the cells and in the bronchiole epithelium. These findings confirm that biomass smoke has important toxic effects on the lung parenchyma, interstitium, and pulmonary vessels that may result in malignancies.
\end{abstract}

KEY WORDS: biomass smoke exposure, bronchoscopy, histopathological changes, lung diseases

Heat releasing sources composed of biological material are called biomass'. Burning biomass and poor indoor air exchange may cause chronic lung diseases, interstitial lung disease, and cancer. The use of biomass in Turkey is common due to social, economic, and cultural reasons.
The most important aetiological factor in biomassrelated disease is the pollutant being released (1-3). In suburban areas of Turkey women who make fire, bake, and cook with biomass primarily composed of cowpat are exposed to its smoke. that may contain harmful pollutants such as aldehydes, phenols, and 
toluene $(4,5)$. Incomplete burning of animal waste also releases $\mathrm{CO}, \mathrm{NO}_{2}$, and $\mathrm{SO}_{2}(5)$. Exposure in this population, who are poor and have little access to healthcare services, is often associated with chronic lung damage and respiratory infections.

Our earlier experimental study (6) showed histopathological changes in the trachea and the lungs of rats exposed to biomass smoke for one hour a day for three, six, and nine months. Histopathological findings included lymphocyte, eosinophil, and macrophage infiltrations in the interstitium, small papillary structures in the airway mucosa, thickening of the intimae and media of the pulmonary vessels, narrowing of pulmonary vessel lumens, and papillary adenomatous proliferation of the mucosa (6).

The aim of this study was to determine if similar changes occurred in human lungs after biomass smoke exposure. The number of studies which include bronchoscopy in people exposed to biomass smoke is very small and we hoped to fill in this gap by analysing histopathological findings in transbronchial tissue samples from women who had bronchoscopy performed and who were exposed to biomass smoke.

\section{MATERIALS AND METHODS}

This prospective study was approved by bioethics committees of the Yuzuncu Yil University Faculty of Medicine, and observed the Declaration of Helsinki. It was carried out between January 2007 and September 2009 in 42 women who had pathological findings on lung roentgenograms. The women were exposed to biomass smoke for various hour-years (1 hour-year equals 365 hours of exposure per year with average exposure of 1 hour a day). Biomass exposure in the absence of other pollutant exposure is rare in men, and we excluded male patients from the study. Women who smoked tobacco and were exposed to biomass smoke were also excluded from the study. All of the patients lived in the countryside, which excludes an influence of metropolitan atmospheric air pollution to a reasonable extent.

Cigarette smoking and biomass exposure were determined by interview. The length of exposure to biomass smoke was expressed in years and the density of exposure in hours per day. Total exposure is therefore expressed in hour-years.

Posterior-anterior lung roentgenograms and findings of computed tomography (CT) scans were analysed to confirm that the patients met our inclusion criteria.

Bronchoscopy was performed in all of the patients included in the study according to our diagnostic algorithm. All patients signed an informed consent form before the procedure. They were also tested for platelet count, prothrombin time, and partial thromboplastin time. The patients underwent bronchoscopy after a four-hour fast and remained in the same operation room with resuscitation equipment ready throughout the procedure. Those experiencing a bronchospasm received a bronchodilator. For local anaesthesia they received an $8 \mathrm{mg} \mathrm{kg}^{-1}$ dose of $2 \%$ lidocaine solution in spray. The nasal passageway was preferred for the use of fiberoptic bronchoscope (Olympus, Center Valley, PA, USA). Patients were monitored by pulse oximetry. Macroscopic finding were recorded. Transbronchial biopsy was collected from sub-lobe basal segments of patients with interstitial changes and common lesions, and from the lobes with limited lesions. Three hours after the transbronchial biopsy, a posterior-anterior lung roentgenogram was taken to exclude pneumothorax. Forceps biopsy was performed in patients with endobronchial lesions, and transbronchial needle aspiration biopsy in patients with mediastinal lymphadenopathy. Bacteriological and cytopathological analyses were performed on the bronchial lavage and biopsy samples. Anthracotic changes, inflammatory infiltration, thickening at alveolar septum, fibrosis, and malignancies were assessed by an experienced pathologist. Photos of histopathological samples were taken microscopically.

Continuous variables were expressed as mean \pm standard deviation, while categorical variables were expressed as number and percentage. To determine the difference between the diagnostic groups in terms of continuous variables, we used the Mann-Whitney $U$ test. To determine the relationships between the diagnostic groups and other categorical variables, we used the chi-square test and calculated the odds ratio. Statistical significance was set at $P<0.05$. Data were processed using the SPSS (version 16) statistical software.

\section{RESULTS}

The age, biomass exposure, bronchoscopy findings, and diagnosis for individual patients are shown in Table 1. Average biomass exposure years and total 
Table 1 Age of the patients, duration of exposure to biomass smoke, bronchoscopy findings, and diagnosis

\begin{tabular}{|c|c|c|c|c|}
\hline $\begin{array}{l}\text { Age / } \\
\text { years }\end{array}$ & $\begin{array}{c}\text { Biomass } \\
\text { exposure / } \\
\text { hour-years }\end{array}$ & $\begin{array}{l}\text { Years of } \\
\text { exposure }\end{array}$ & Bronchoscopy findings & Diagnosis \\
\hline 36 & 8.5 & 11 & Normal & Chronic bronchitis \\
\hline 59 & 25.7 & 35 & $\begin{array}{l}\text { Narrowing in the orifice of apicoposterior segment of the } \\
\text { left upper lobe }\end{array}$ & Chronic bronchitis \\
\hline 51 & 25.7 & 29 & Anthracotic plaque in the orifice of right upper lobe & Chronic bronchitis \\
\hline 69 & 38.5 & 45 & $\begin{array}{l}\text { Hyperaemia and swelling in the lingular segment of the } \\
\text { left upper lobe }\end{array}$ & Chronic bronchitis \\
\hline 63 & 21.4 & 30 & Normal & $\begin{array}{l}\text { Chronic } \\
\text { bronchitis+ILD }\end{array}$ \\
\hline 60 & 34.2 & 35 & Normal & $\begin{array}{l}\text { Chronic } \\
\text { bronchitis+ILD }\end{array}$ \\
\hline 70 & 51.4 & 43 & $\begin{array}{l}\text { Anthracotic plaque in the orifice of right upper lobe, and } \\
\text { pale mucosa }\end{array}$ & $\begin{array}{l}\text { Chronic bronchitis } \\
+ \text { ILD }\end{array}$ \\
\hline 59 & 34.2 & 33 & Normal & COPD+ILD \\
\hline 61 & 34.2 & 36 & Normal & COPD+ILD \\
\hline 51 & 14.2 & 30 & Mass in the lingular segment of the left upper lobe & Oesophageal cancer \\
\hline 43 & 25.7 & 15 & Normal & ILD \\
\hline 69 & 25.7 & 41 & Mucosal erythema and oedema & ILD \\
\hline 54 & 25.7 & 32 & Normal & ILD \\
\hline 65 & 38.5 & 40 & Widespread anthracosis and swelling in mucosa & ILD \\
\hline 77 & 42.8 & 50 & Normal & ILD \\
\hline 69 & 42.8 & 37 & Widespread anthracotic plaques & ILD \\
\hline 63 & 17.1 & 31 & Indirect tumour findings in left bronchial system & ILD+PE \\
\hline 64 & 17.1 & 29 & Narrowing in the orifice of right middle lob & Lung cancer \\
\hline 65 & 17.1 & 32 & $\begin{array}{l}\text { Anthracosis and narrowing in the orifice of anterior } \\
\text { segment of right upper lobe }\end{array}$ & Lung cancer \\
\hline 57 & 17.1 & 28 & A mass in right middle lobe & Lung cancer \\
\hline 58 & 17.1 & 35 & A mass in right main bronchus & Lung cancer \\
\hline 46 & 21.4 & 20 & A mass in left main bronchus & Lung cancer \\
\hline 57 & 25.7 & 32 & A mass in right main bronchus & Lung cancer \\
\hline 71 & 25.7 & 50 & A mass in the intermediary bronchus & Lung cancer \\
\hline 58 & 30.0 & 32 & A mass in the intermediary bronchus & Lung cancer \\
\hline 43 & 30.0 & 18 & A mass in the intermediary bronchus & Lung cancer \\
\hline 55 & 34.2 & 31 & Narrowing in the orifice of right upper lobe & Lung cancer \\
\hline 66 & 34.2 & 43 & A mass in left main bronchus & Lung cancer \\
\hline 65 & 38.5 & 40 & Paralysis of left vocal cord and mass in left main broncus & Lung cancer \\
\hline 74 & 42.8 & 51 & $\begin{array}{l}\text { Submucosal swelling and narrowing in the orifice of right } \\
\text { upper lobe }\end{array}$ & Lung cancer \\
\hline 76 & 42.8 & 60 & Total obstruction in right lower lobe bronchus & Lung cancer \\
\hline 68 & 42.8 & 41 & Narrowing in the orifice of left upper lobe & Lung cancer \\
\hline 68 & 38.5 & 39 & Normal & Pancreatic cancer \\
\hline 34 & 1.1 & 14 & Normal & Pneumonia \\
\hline 50 & 21.4 & 29 & Subcarinal enlargement & Sarcoidosis \\
\hline 53 & 25.7 & 31 & Subcarinal enlargement & Sarcoidosis \\
\hline 54 & 25.7 & 33 & Subcarinal enlargement & Sarcoidosis \\
\hline 56 & 34.2 & 29 & Subcarinal enlargement & Sarcoidosis \\
\hline 45 & 25.7 & 17 & Erythema in the orifice of right lower lobe & Tuberculosis \\
\hline 59 & 25.7 & 40 & Normal & Tuberculosis \\
\hline 55 & 30.0 & 35 & $\begin{array}{l}\text { Narrowing in the orifice of posterior and anterior } \\
\text { segments of right upper lobe }\end{array}$ & Tuberculosis \\
\hline 67 & 34.2 & 42 & $\begin{array}{l}\text { Anthracosis and obstruction in the orifice of superior } \\
\text { segment of right lower lobe }\end{array}$ & Tuberculosis \\
\hline
\end{tabular}

$C O P D=$ chronic obstructive pulmonary disease $; I L D=$ interstitial lung disease $; P E=$ pulmonary embolism 
exposure were $(13 \pm 5)$ years and $(28.6 \pm 9.1)$ houryears, respectively. The utilised biomass fuel is called tezek, and is produced by dehumidifying animal manure. The percent (mean $\pm \mathrm{SD}$ ) of the predicted $\mathrm{FEV}_{1}$ and $\mathrm{FVC}$ were $(90 \pm 7) \%\left[(2.6 \pm 0.48) \mathrm{L} \mathrm{s}^{-1}\right]$ and $(87.8 \pm 7.1) \%\left[(2.9 \pm 0.44) \mathrm{L} \mathrm{s}^{-1}\right]$, respectively, and the $\mathrm{FEV}_{1} / \mathrm{FVC}$ was $(85 \pm 6) \%$. Seven percent of the patients had an $\mathrm{FEV} / \mathrm{FVC}$ below $70 \%$.

Radiological findings were as follows: mass (18 patients, $42.9 \%$ ); reticulonodular opacity (13 patients, $31 \%$ ); mediastinal lymphadenopathy (11 patients, $26.2 \%)$; pleuroparenchymal fibrotic stripes (8 patients, $19 \%$ ); dilatation of the pulmonary artery (6 patients, $14.3 \%$ ); ground glass opacities (5 patients, $11.9 \%$ ); consolidation (4 patients, $9.5 \%$ ); mosaic perfusion (4 patients, $9.5 \%$ ); segmenter or subsegmenter atelectasis (3 patients, $7.1 \%$ ); and bronchiectasis (3 patients, $7.1 \%$ ).

Bleeding was seen in only one patient as a bronchoscopy complication and was controlled by lavage with a solution including adrenalin. Pneumothorax was not observed in any of the patients. The main findings of bronchoscopy were indirect tumour findings such as oedema, erythema, and narrowing of the bronchus, indicating acute and chronic airway inflammation. Findings of chronic bronchitis included swollen mucosa, purulent sputum, and dark blue or black anthracotic plates, generally in the upper lung lobes, and especially in the bifurcation regions. Direct tumour findings included endobronchial neoplasm, mucous instability, and increased blood vessels.

We also performed bronchoscopic transbronchial biopsy (16 patients, $38 \%$ ); mucous biopsy (16 patients, $38 \%$ ); transcarinal needle aspiration biopsy (4 patients, $9.5 \%$ ); and bronchial lavage (6 patients, $14 \%)$. Most of the patients had lung cancer and interstitial lung disease. Lung disease in these patients was diagnosed after more than 27 hours per year of biomass smoke exposure. However, one patient with 11 hours per year of biomass smoke exposure had a normal biopsy finding. The incision was performed to find the cause of haemoptysis.

There was a highly negative correlation between interstitial lung disease and lung cancer $(P=0.001)$. That biomass smoke exposure may cause different diseases in different people may partially be explained by a person's genetic predisposition to a disease.

Table 2 shows the histopathological findings in the patients with interstitial lung disease (ILD). Biopsy tissue of four patients was lost during examination.

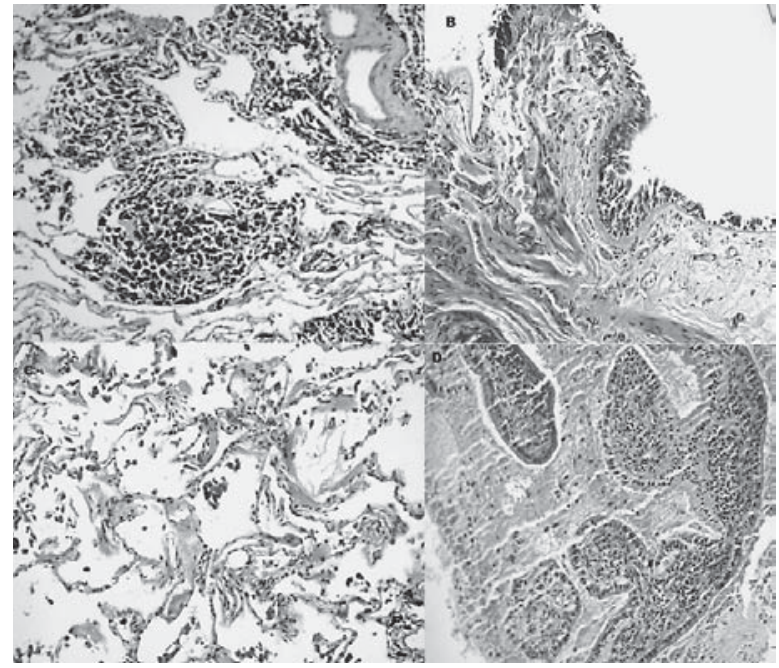

Figure 1 Histology of representative tissue samples obtained by bronchoscopy. The following tissue samples are shown with $H \& E$ staining at 100x magnification except where noted otherwise: (A) Anthracosis in the lung parenchyma with vascular wall thickening; $(B)$ Basal membrane thickening, eosinophilic enhancement in bronchial mucosa (200x); (C) Inflammatory focal thickening of alveolar septipara and lung parenchyma; (D) Dominated by lymphocytes, few neutrophils and plasma cells showing signs of chronic inflammation of the bronchial mucosa

Transbronchial biopsy taken from 16 of 21 patients who were thought to have ILD. Bronchial lavage was performed on five patients. Cytological analysis showed no malignant cells in these patients. Neutrophils were the dominant cell type for many patients. In one patient, lymphocytes accounted for $70 \%$ of the cells. Tissue samples stained with haematoxylin and eosin (H\&E) were examined under a light microscope (Olympus BX50F-3, Olympus Optical Co., Japan) at either 100x or 200x magnification. Figure 1 shows the typical tissue samples obtained by bronchoscopy.

In the interalveolar septum, we observed perivascular and peribronchial neutrophils, lymphocytes, and alveolar macrophage infiltration. In some cases this cell infiltration let to the thickening of the interalveolar septa. In some patients, white blood cells infiltrated the spaces around vessels, the intima and the media of the vessels thickened, and their lumens narrowed. Black coal dust in the form of granular debris or little piles were scattered between the cells. Similar piles were found in the bronchioles on the apical surface of the epithelium and in the intracytoplasmic space. In one patient, nodular fibrotic thickening was observed in some places. Bilateral and many nodular lesions, more obvious in the sub-lobes, were detected by lung tomography in one patient, who 
was thought to have ILD, but the bronchoscopic lavage histopathology did not support this diagnosis. However, a bulk was detected at the head of the pancreas in an abdomen tomography during examination of the patient, and the lung lesions were interpreted as metastasis.

Computer tomography detected a mass indicative of lung cancer in 14 patients, who then underwent bronchoscopy to confirm or rule out this preliminary diagnosis. The following histopathological types of lung cancer were detected: small cell in six patients, squamous cell in two patients, adenocarcinoma in two patients, and bronchoalveolar carcinoma in one patient. In two patients, the malignant epithelial tumour could not be determined by the cell type, and the tumour in one patient was evaluated as benign.

Chronic inflammation in a patient who complained of difficulty swallowing was followed up by endoscopy. Transbronchial biopsy revealed esophageal squamous carcinoma.

One of the four patients with mediastinal lymphadenopathy had right hilar lymphadenopathy and one had a consolidation at the right-mid lobe. The smear obtained by transcarinal thin needle aspiration biopsy did not show malignant cells. Patients diagnosed with sarcoidosis were introduced steroid treatment. All patients with lymphadenopathy showed a degree of regression due to treatment.

Tuberculosis was diagnosed in four patients. Mediastinal lymphadenopathy was established in one; a consolidation in the sub-lobe superior segment of the right lung in another; a consolidation in the sublobe of the right lung together with mediastinal lymphadenopathy in one patient; and a consolidation with fusion fields in the upper lobe of the right lung in one patient. Histopathological analysis showed a negative finding in the first patient, an active chronic inflammation in the second, chronic inflammation in the third, and anthracosis in the fourth. Tuberculosis culture of bronchial lavage tested positive and all four patients were started antituberculosis treatment.

\section{DISCUSSION}

Exposure to biomass in buildings without proper ventilation increases the risk of acute airway infections in children and COPD, ILD, and lung cancer in the adults $(2,3,7,8)$. In Turkey, biomass smoke exposure is an important risk factor for lung diseases in nonsmoking women, especially in rural areas. However, tobacco smoke and biomass smoke-related lung diseases have similar characteristics.

Biomass smoke contains carbon monoxide, nitric acid, sulphur oxides, formaldehyde, polycyclic organic substances, carcinogens like benzopyrene, and particles smaller than 10 micrometers (9). Most of these components are mutagenic in vitro (9). Smoke is an irritant toxic to cilia and contains coagulant agents which affect the respiratory system defence and increase the risk of chronic lung infection (10, 11). Domestically-acquired particulate lung disease (DAPLD) is a term used to identify biomass-related lung diseases (12). DAPLD manifests itself in a broad range of disorders from chronic bronchitis and COPD to advanced interstitial lung disease and malignancy.

Studies around the world have established a relationship between lung disease and exposure to biomass smoke. Pandey et al. (13) have shown that COPD prevalence rises with age and is greater Nepalese men than women (13). Akhtar et al. (9) identified chronic bronchitis in 100 of 1426 Pakistani women burning biomass and established a strong relationship between bronchitis and biomass use compared to a control group. Demirtaș et al. (2) found that women who exposed to biomass smoke were significantly more prone to COPD than unexposed women. Özbay et al. (1) detected a severe obstruction and an increase in the lung volume in pulmonary function tests of biomass-exposed women. They observed radiologically diffuse emphysema, thickening at interlobular septa, focal emphysematosa fields, and an increase in bronchovascular arborisation. They showed that biomass smoke increased obstructive and restrictive effects on the pulmonary function and structure. Our results seem to confirm the above studies, especially in reference to COPD. Sandaval et al. (14) have suggested that dense anthracotic staining is more characteristic of women exposed to biomass than of heavy tobacco smokers. Chung et al. (15) found anthracotic staining in people exposed to biomass smoke, in heavy smokers, miners, and city population. Bruce et al. (16) found that tuberculosis prevalence was higher in homes using biomass than in homes using cleaner combustibles. Similarly, Perez Podilla et al. (17) support the finding that heating with biomass at home contributes to tuberculosis. Shprykov et al. (18) found that tobacco smoke had a great effect on the structure of Mycobacterium tuberculosis. These structural changes suggest that smoke supports bacterial growth. In our study, in the four pulmonary tuberculosis diagnosed cases, dark anthracotic 
pigmentation and chronic inflammation were detected that may have contributed to bacterial growth.

Biomass smoke contains numerous chemicals that are known or suspected human carcinogens. Mutations in human cancer are the most frequent in the p53 gene (19). Mutation in the p53 gene is found in $50 \%$ of non-small cell lung cancers and in $90 \%$ of small cell lung cancers (20).

Cigarette smoke contains almost 60 carcinogenic components including benz(a)pyrene $(\mathrm{BaP})$ and nicotine-derived nitrosamine ketone (NNK), which induce p53 gene mutations (21). Wood smoke contains $\mathrm{BaP}$, just like cigarette smoke (16). Delgado et al. (3) detected mutation in the p53 gene in lung cancer cases related to wood smoke and in cancers caused by cigarette smoke. They proposed that, just like cigarette smoke, wood smoke can play a role in lung cancer. Malatz et al. (22) found higher frequency of genetic polymorphism in glutathione S-transferase enzymes in non-smoking lung cancer patients who were exposed to wood smoke for more than 20 years. In the regions of China in which lung cancer is common in humans, Liang et al. (23) investigated exposure to coal and wood smoke in mice and rats and found that wood smoke exposure involved a higher risk of cancer than control, but a lower risk compared to coal smoke exposed animals. Consistent with all these studies, our study has shown that biomass smoke exposure is an important risk factor for human lung cancer

According to Gold et al. (24), cooking may produce high levels of $\mathrm{BaP}$ that equal a packs of cigarettes a day. In another study (16), BaP levels detected over three hours of cooking a day equalled two packs of cigarettes a day. These analogies help to explain how biomass smoke exposure can contribute to the growth of malignancy. Behera et al. (25) showed that adenocarcinoma was the dominant histopathological type of lung cancer in non-smoking women exposed to wood smoke. Similarly in Delgado et al. (3), the main histopathological type was adenosarcoma in patients exposed to wood smoke (3). Hoffman et al. (26) showed that nicotine-derived nitrosamine ketone (NNK), contributed to adenocarcinoma and $\mathrm{BaP}$ to squamous cell carcinoma in lab animals. It is thought that wood smoke, like cigarette smoke, contains BaP, but it may also contain NNK and other carcinogens. In our patients, small cell carcinoma was the primary type of lung cancer, possibly due to a specific composition of the biomass.

Kajdaz et al. (27) found a significant correlation between wood smoke exposure and sarcoidosis. In another study (28) wood burning and organic dust exposure had a significantly higher correlation with sarcoidosis. In our study, four patients were diagnosed with sarcoidosis.

Chronic biomass smoke exposure changes the defense mechanisms of the lung mucociliary system and decreases the antibacterial capacity of macrophage $(15,29)$. It may cause bronchial narrowing or blockage due to anthracosis or mucoid secretion piles at distal lung fields, and development of pneumonia at segments or lobes. Repeating infections increase bronchiectasis. Consistent with our study, Kara et al. (30) concluded that biomass smoke caused many diseases, from chronic bronchitis to interstitial lung disease.

Like in some of our patients, a transbronchial biopsy conducted in a patient exposed to wood smoke in India showed the existence of coal macules (31). The main pathological changes in the transbronchial tissue samples of patients exposed to inorganic dust were similar to other interstitial lung diseases (32-34). The samples showed focal thickening of the alveolar septum and a mix of inflammatory infiltration, fibrosis and basal membrane thickening. Restrepo et al. (35) found similar pathological fibrotis changes in animals and patients exposed to wood smoke for a long time. Ramage et al. (36) identified a similar relationship between interstitial lung disease and wood smoke exposure.

Table 2 Histopathological features of patients $(N=11)$ with interstitial lung disease

\begin{tabular}{lc} 
Histopathology Feature & $\begin{array}{c}\text { Patients with feature } \\
\text { n (\%) }\end{array}$ \\
\hline Anthracotic pigment & $7(63)$ \\
\hline Basal membrane thickening & $6(54)$ \\
\hline Alveolar septal thickening & $2(18)$ \\
\hline Goblet cell metaplasia & $2(18)$ \\
\hline Fibrosis & $1(9)$ \\
\hline Squamous metaplasia & 0 \\
\hline Chronic inflammation & $11(100)$ \\
\hline
\end{tabular}


Our study has showed that exposure to biomass can cause histopathological lung lesions that range from the upper airway inflammation to interstitial fibrosis and malignancy. These histopathological changes provide evidence of specific diseases attributable to biomass smoke exposure in nonsmoking women. One of the limitations of our study is that we have not established whether the exposed women were also exposed to secondary tobacco smoke.

\section{Acknowledgements}

This work was supported by the Research Fund of Yuzuncu Yil University (No; 2007-TF-U121). The authors would like to acknowledge the professional editorial assistance of Dr. Belinda Peace.

\section{REFERENCES}

1. Ozbay B, Uzun K, Arslan H, Zehir I. Functional and radiological impairment in women highly exposed to indoor biomass fuels. Respirology 2001;6:255-8.

2. Demirtaş N, Seyfikli Z, Topçu S. Sivas bölgesinden hastanemize başvuran kadın hastalarda biomass kullanımı ile KOAH arasındaki ilişki [The relationships between traditional biomass combustion and development of COPD in women from the Sivas area, in Turkish]. Solunum Hastalıkları Dergisi 1999;10:148-55.

3. Delgado J, Martinez LM, Sánchez TT, Ramirez A, Iturria C, González-Avila G. Lung cancer pathogenesis associated with wood smoke exposure. Chest 2005;128:124-31.

4. Pandey MR, Regmi HN, Neupane RP, Gautam A, Bhandari DP. Domestic smoke pollution and respiratory function in rural Nepal. Tokai J Exp Clin Med 1985;10:471-81.

5. Boleij JSM, Ruigewaard P, Hoek F, Thairu H, Wafula E, Onyango F, de Koning H. Domestic air pollution from biomass burning in Kenya. Atmos Environ (1967) 1989;23:1677-81.

6. Ozbay B, Yener Z, Acar S, Kanter M. Histopathological changes in the lung of rat following long - term exposure to biomass smoke. Turkiye Klinikleri J Med Sci 2009;29:87783.

7. de Koning HW, Smith KR, Last JM. Biomass fuel combustion and health. Bull World Health Organ 1985;63:11-26.

8. Samet JM, Tielsch J. Commentary: Could biomass fuel smoke cause anaemia and stunting in early childhood? Int J Epidemiol 2007;36:130-1.

9. Akhtar T, Ullah Z, Khan MH, Nazli R. Chronic bronchitis in women using solid biomass fuel in rural Peshawar, Pakistan. Chest 2007;132:1472-5.

10. Tuthill RW. Woodstoves, formaldehyde, and respiratory disease. Am J Epidemiol 1984;120:952-5.

11. Fick RB Jr., Paul ES, Merrill WW, Reynolds HY, Loke JS Alterations in the antibacterial properties of rabbit pulmonary macrophages exposed to wood smoke. Am Rev Respir Dis 1984;129:76-81.
12. Samet JM, Marbury MC, Spengler JD. Health effects and sources of indoor air pollution. Part I. Am Rev Respir Dis 1987;136:1486-508.

13. Pandey MR. Domestic smoke pollution and chronic bronchitis in a rural community of the Hill Region of Nepal. Thorax 1984;39:337-9.

14. Sandoval J, Salas J, Martinez-Guerra ML, Gómez A, Martinez C, Portales A, Palomar A, Villegas M, Barrios R. Pulmonary arterial hypertension and cor pulmonale associated with chronic domestic woodsmoke inhalation. Chest 1993;103:12-20.

15. Chung MP, Lee KS, Han J, Kim H, Rhee CH, Han YC, Kwon OJ. Bronchial stenosis due to anthracofibrosis. Chest 1998;113:344-50.

16. Bruce N, Perez-Padilla R, Albalak R. Indoor air pollution in developing countries: a major environmental and public health challenge. Bull World Health Organ 2000;78:107892.

17. Pérez-Padilla R, Pérez-Guzmán C, Báez-Saldaña R, TorresCruz A. Cooking with biomass stoves and tuberculosis: a case control study. Int J Tuberc Lung Dis 2001;5:441-7.

18. Shprykov AS, Zhdanov VZ, Lazovskaia AL, Levchenko TN. [Tobacco smoke condensate-induced structural changes in Mycobacteria tuberculosis, in Russian]. Probl Tuberk 2002:39-41

19. Hollstein M, Sidransky D, Vogelstein B, Harris CC. p53 mutations in human cancers. Science 1991;253:49-53.

20. Robles AI, Linke SP, Harris CC. The p53 network in lung carcinogenesis. Oncogene 2002;21:6898-907.

21. Pfeifer GP, Denissenko MF, Olivier M, Tretyakova N, Hecht SS, Hainaut P. Tobacco smoke carcinogens, DNA damage and p53 mutations in smoking-associated cancers. Oncogene 2002;21:7435-51

22. Malats N, Camus-Radon AM, Nyberg F, Ahrens W, Constantinescu V, Mukeria A, Benhamou S, Batura-Gabryel H, Bruske-Hohlfeld I, Simonato L, Menezes A, Lea S, Lang M, Boffetta P. Lung cancer risk in nonsmokers and GSTM1 and GSTT1 genetic polymorphism. Cancer Epidemiol Biomarkers Prev 2000;9:827-33.

23. Liang CK, Quan NY, Cao SR, He XZ, Ma F. Natural inhalation exposure to coal smoke and wood smoke induces lung cancer in mice and rats. Biomed Environ Sci 1988;1:4250.

24. Gold JA, Jagirdar J, Hay JG, Addrizzo-Harris DJ, Naidich DP, Rom WN. Hut lung. A domestically acquired particulate lung disease. Medicine (Baltimore) 2000;79:310-7.

25. Behera $\mathrm{D}$, Balamugesh $\mathrm{T}$. Indoor air pollution as a risk factor for lung cancer in women. J Assoc Physicians India 2005; 53:190-2.

26. Hoffmann D, Hoffmann I, El-Bayoumy K. The less harmful cigarette: a controversial issue. a tribute to Ernst L. Wynder. Chem Res Toxicol 2001;14:767-90

27. Kajdasz DK, Lackland DT, Mohr LC, Judson MA. A current assessment of rurally linked exposures as potential risk factors for sarcoidosis. Ann Epidemiol 2001;11:111-7.

28. Kreider ME, Christie JD, Thompson B, Newman L, Rose C, Barnard J, Bresnitz E, Judson MA, Lackland DT, Rossman MD. Relationship of environmental exposures to the clinical phenotype of sarcoidosis. Chest 2005;128:207-15.

29. Grigg J. Effect of biomass smoke on pulmonary host defence mechanisms. Paediatr Respir Rev 2007;8:287-91. 
30. Kara M, Bulut S, Tas F, Akkurt I, Seyfikli Z. Evaluation of pulmonary changes due to biomass fuels using highresolution computed tomography. Eur Radiol 2003;13:23727.

31. Saini V, Nadal R, Kochar S, Mohapatra PR, Deb A. Woodsmoke exposure: an unusual cause of miliary mottling on X-ray chest. Indian J Chest Dis Allied Sci 2003;45:273-6.

32. Pathology standards for coal workers' pneumoconiosis. Report of the Pneumoconiosis Committee of the College of American Pathologists to the National Institute for Occupational Safety and Health. Arch Pathol Lab Med 1979;103:375-432.
33. Ziskind M, Jones RN, Weill H. Silicosis. Am Rev Respir Dis 1976;113:643-65.

34. McDonald JC, editor. Recent Advances in Occupational Health. New York (NY): Churchill Livingstone; 1981.

35. Restrepo J, Reyes P, de Ochoa P, Patina E. Neumoconiosis por inhalación de humo de leña [Pneumoconiosis due to inhalation of wood smoke, in Spanish]. Acta Med Colombiana 1983;8:191-204.

36. Ramage JE Jr., Roggli VL, Bell DY, Piantadosi CA. Interstitial lung disease and domestic wood burning. Am Rev Respir Dis 1988;137:1229-32. 


\section{Sažetak}

\section{KRONIČNI UČINCI AMBIJENTALNOGA DIMA IZ BIOMASE NA HISTOPATOLOGIJU PLUĆA U LJUDI: OPIS NIZA SLUČAJEVA}

Biomasa se u mnogim zemljama u razvoju rabi za gorivo. Čestice i plinovi izgorene biomase mogu dovesti do plućnih promjena. Ovdje smo istražili histološke promjene u plućima ljudi uzrokovane biomasom. Ovo je prospektivno ispitivanje obuhvatilo 42 nepušačice izložene dimu iz biomase u kojih je ocijenjena izloženost dimu, uzeta povijest bolesti, napravljen fizikalni pregled te analizirani radiološki, bronhoskopski

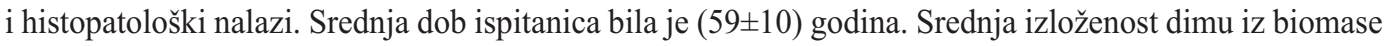

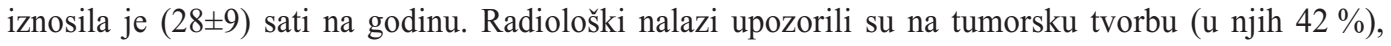
retikulonodularna zasjenjenja (31\%), limfadenopatiju medijastinuma (26\%), fibrozne promjene pleure i plućnog parenhima (19 \%), proširenje plućne arterije (14 \%), sliku smrvljenog stakla (11 \%), sliku mozaične perfuzije (9\%), konsolidacije (9\%), segmentnu i subsegmentnu atelektazu (7\%) te bronhijektazije (7\%). U njih $35 \%$ dijagnosticiran je rak pluća, u $31 \%$ bolesti plućnog intersticija, u $9 \%$ sarkoidoza, u $9 \%$ tuberkuloza, u $4 \%$ KOPB, u $9 \%$ kronični bronhitis te u $4 \%$ metastaze. Bronhoskopija je pokazala pilije, edem, eritem, sužavanje bronhija, endobronhijalni tumor, neurednu sluznicu, izrazitiju vaskularizaciju, plavo-crne antrakotične plakove, otjecanje sluznice te purulentnu sekreciju. Transbronhijalnom biopsijom pronađeni su neutrofili i limfociti u perivaskularnom, peribronhiolarnom tkivu i interalveolarnim septumima, zadebljanje vezivnoga tkiva, zadebljanje bazalne membrane, zadebljanje interalveolarnih septuma, zadebljanja stijenke žila intimalno i medijalno te suženje njihova lumena, crna antrakoza između stanica te u epitelu bronhiola. Sve to upozorava na značajne promjene uzrokovane biomasom, koje obuhvaćaju zloćudne formacije uslijed toksičnoga djelovanja na plućni parenhim, intersticij i žile.

KLJUČNE RIJEČI: izloženost dimu biomase, plućne bolesti

\section{CORRESPONDING AUTHOR:}

Bunyamin Sertogullarindan

Yuzuncu Yil University Medical Faculty

Arastirma Hastanesi Kazım Karabekir caddesi

65200 Van, Turkey

E-mail: bunyaminsert@hotmail.com 